Contents list available at IJRED website

Int. Journal of Renewable Energy Development (IJRED)

Journal homepage: www.ijred.com

\title{
Renewable Energy in Eastern North Africa in Terms of Patterns of Coupling to Czisch European HVDC Super Grid
}

\author{
K. Boubakera ${ }^{*}$, A. Colantonib and E. Allegrini ${ }^{b}$ \\ a École Supérieure de Sciences et Techniques de Tunis (ESSTT), Université de Tunis/ 63 Rue Sidi Jabeur 5100, Mahdia, TUNISIA \\ ${ }^{b}$ Department of Agriculture, Forest, Nature and Energy (DAFNE), University of Tuscia, Via S. Camillo de Lellis snc, 01100 Viterbo, ITALY
}

\section{Article history:}

Received Feb 28, 2013 Received in revised form May 8, 2013 Accepted May 10, 2013 Available online

\begin{abstract}
In this study, wind energy potential and perspectives in the eastern North Africa region (Tunisia) have been investigated in terms of connectivity to the projected Czisch European HVDC super grid. A simplified extracted scheme of this grid has been used as a guide to optimize transportation efficiency through the whole net. Wind, as an available and easily exploitable renewable energy was showing to have a promising future for 2025 horizon in the context of a connected net with the European Union, despite local sub-grids disparities. This is also to emphasis HVDC technology adequacy for economical power transmission over very long distances and connection between differently established grids.
\end{abstract}

Keywords: 3D optimizing abacus; renewable energy; Czisch HVDC super grid; European Union; North Africa; wind energy

\section{Introduction}

Tunisia is a very promising country in the matter of wind energy as well as a key participant in the renewable energy area. Due to its strategic geographical location at the middle of the Mediterranean basin, Tunisia holds one of the highest wind energy potentials in the eastern part of the basin (Khasri 1986; Hadj Sassi and Gattoufi 1988; Bahri 1991; United Nations Environnement Programme (UNEP) 2004; Ben Jannet Allal 2005; Ben Amar et al. 2006; Research Projects Federee (PRF) 2007; Societe Tunisienne de l'Electricite et du Gaz (STEG) 2010). During the last decade, primary energy average consumption increased by $3.7 \%$ per year whereas the average energy production increased, for the same period, only by $2.3 \%$. Since 2001 , Tunisia has become an importer of primary energy (Ben Jannet Allal, 2005; Societe Tunisienne de l'Electricite et du Gaz (STEG) 2010). Recently, and in order to balance this deficit, Tunisian Company of Electricity and Gas (STEG) has 20 power stations of diversified production of energy that are composed of combined cycle, steam and gas turbines and hydraulic and wind turbines (Societe Tunisienne de l'Electricite et du Gaz (STEG) 2010). In this context, wind energy sector is considered as a promising source in the improvement of the energy balance and the environmental protection.

Not far from this area, and as stated by Czisch (2008, 2011), the recently launched European Renewable Grid Initiative ERGI is claimed to be capable of not only linking remote wind farms, but also drawing energy from millions of micro-generation devices. Producing unit size is critical to this grid since a grid based on micro-generation devices such as small scale wind turbines would prove much less efficient then one built around large scale renewable energy technologies.

In this paper, we give some features of adequacy of future and actual projects in the wind energy domain in the eastern North Africa region, in terms of both efficiency and connectivity to the European Renewable Grid Initiative ERGI. An electrically equivalent circuit along with a scientifically founded optimizing protocol gives evidence to this analysis.

\section{Wind energy in Tunisia}

\subsection{Actual state of the art}

According to Hadj Sassi and Gattoufi (1988), wind energy potential in Tunisia is significant and may 
reach annually as much as $1.0 \mathrm{MWh} / \mathrm{m}^{2}$. In Fig. 1, three main windy regions can be identified. The first and most important zone extends from the northeastern coast to the north-western coast, the second covers the gulf of Gabes and the third is located at the mountainous region of Thala. The windiest zone is that of the north-eastern region of Cap-Bon where the mean yearly wind energy exceeds $900 \mathrm{kWh} / \mathrm{m}^{2}$.

From a historical point of view, wind energy has been exploited for water pumping for a long time in many parts of the country using traditional windmills. Recently, a new project has been engaged by the Tunisian Company of Electricity and Gas (STEG) for installing a wind farm for electricity generation with a total production capacity of $100 \mathrm{MW}$ in EI-Hawaria (Cap-Bon region). The wind farm will be composed of a series of AE-30 wind turbines.

Until now only one wind farm has been built, in Sidi Daoud (Gouvernement Nabeul) near Cap Bon (Figure 2). It has been in operation since 2000 (Ben Amar et al. 2006). Average annual wind velocity at this location is $8.4 \mathrm{~m} / \mathrm{s}$ at a height of $30 \mathrm{~m}$. The project was put out to tender in 1996 on the basis of a feasibility study that was drawn up between 1990 and 1992. In 2003 the wind farm was expanded by the addition of 12 turbines with a capacity of $8.7 \mathrm{MW}$. It now has a total generating capacity of almost $20 \mathrm{MW}$.

As part of its $10^{\text {th }}$ development plan (2003-2007), local instances are planning the construction of wind farms with a capacity of about 100 MW. A prequalification round for the subsequent bidding process was initiated at the beginning of 2004, and the wind farms are due to enter operation no later than 2007. An additional construction of a further $200 \mathrm{MW}$ by private investors is envisaged for the period from 2008 to 2011 under the $11^{\text {th }}$ development plan.

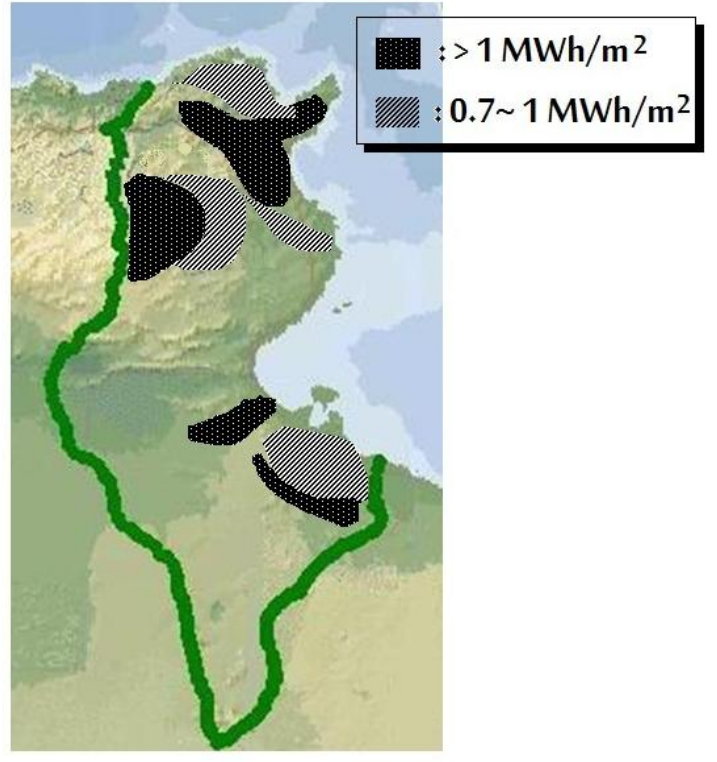

Fig. 1 Tunisian wind chart

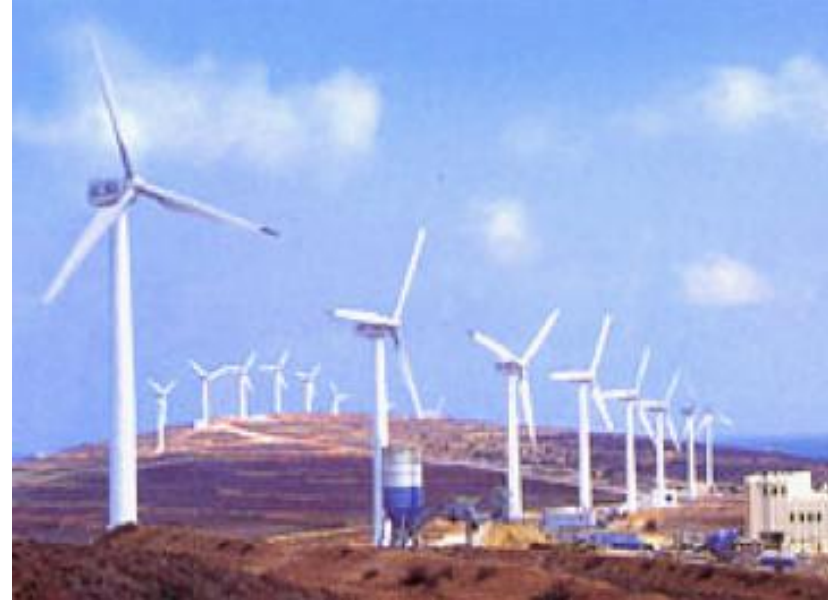

Fig. 2 Sidi Daoud wind farm

Nevertheless, according to Kerkeni et al. (2002), Mouldi (2003), and Khemiri and Hassairi (2005), Tunisia doesn't seem to take concrete measures to move towards further liberalisation and to open wind energy sectors to competition, despite showing an interest in new concepts which consist of bringing technology and deserts into service for energy, water and climate security.

\subsection{Projects and Perspectives}

Tunisia is one of the most developed countries in the North Africa zone, its geographic location has several advantages for extensive use of wind energy. As stated by Trieb and Nitsch (1998), Trieb and MüllerSteinhagen (2008) and Trieb et al. (2011), Tunisia's renewable electricity targets in the long run, by 2025, to reach $20 \%$ overall renewable coverage, in the proportions of $7: 2: 1$ to CSP, wind and photovoltaic, respectively (Fig. 3).

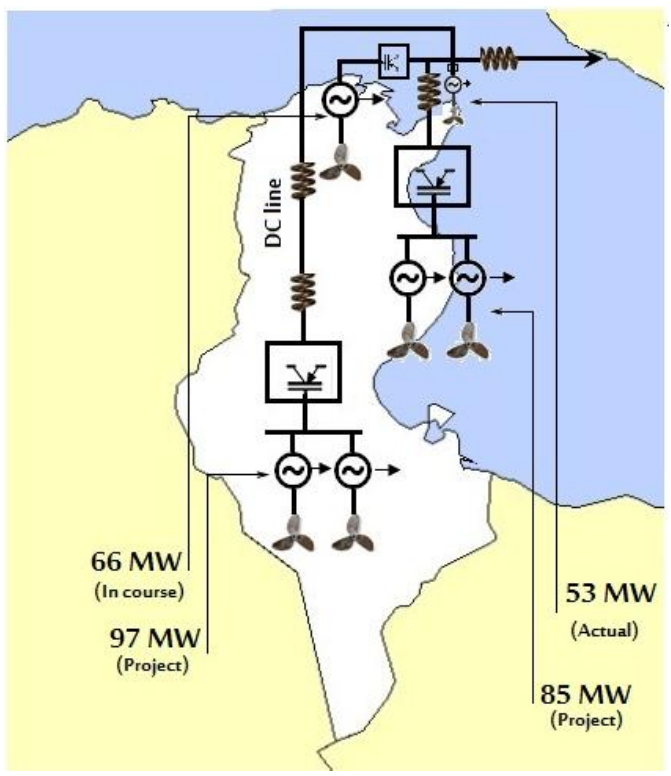

Fig. 3 Wind near perspectives (short term) 


\section{Features of a HVDC Connectable Local Net}

In the last two decades, wind and solar energy, among others, has received significant attention in North Africa as in other regions of the world. As hydropower faces stagnating expansion potential in this region due to geographical limitations, major efforts are developed toward wind and solar technologies. The first motivation is undoubtedly the increase of the global demand of the region (Fig. 4).

Nevertheless, and despite a favourable global solar radiation, the currently-installed wind plants in Tunisia, corresponds to a minor contribution (less than $1.5 \%$ of the overall installed electricity capacity of the region in 2009 as stated by Brand and Zingerle (2011).

In the same context, it is known that EU has relatively limited low-cost power production potentials from renewable energy sources, but it could import electricity produced from renewable energy sources in North-Africa (solar PV and CSP) and eventually Eastern Europe (wind and biomass). This need depends partially on connections. Existing connections are quite reduced to the unique $400 \mathrm{kV}$ line between Morocco and Spain. It represents the oldest transcontinental power connection across the Mediterranean Sea, and is likely to be seconded by a DC undersea cable between Tunisia and Italy. A different configuration has been proposed (Czisch 2011): the HVDC (High Voltage Direct Current) transmission system which connects a network dominated by wind power sites throughout the entire supply area. In this context, the scheme presented by Gregor Czisch (Czisch 2008; 2011): the European HVDC super grid (Fig. 5) is of a big interest.

A major advantage of this grid is the possibility, for each region to specialize in the renewable technologies that suit it best while maintaining connection to a single grid. Tunisia, for example, has promising wind potential, Algeria has rich solar radiation and Iceland is rather rich in geothermic resources.

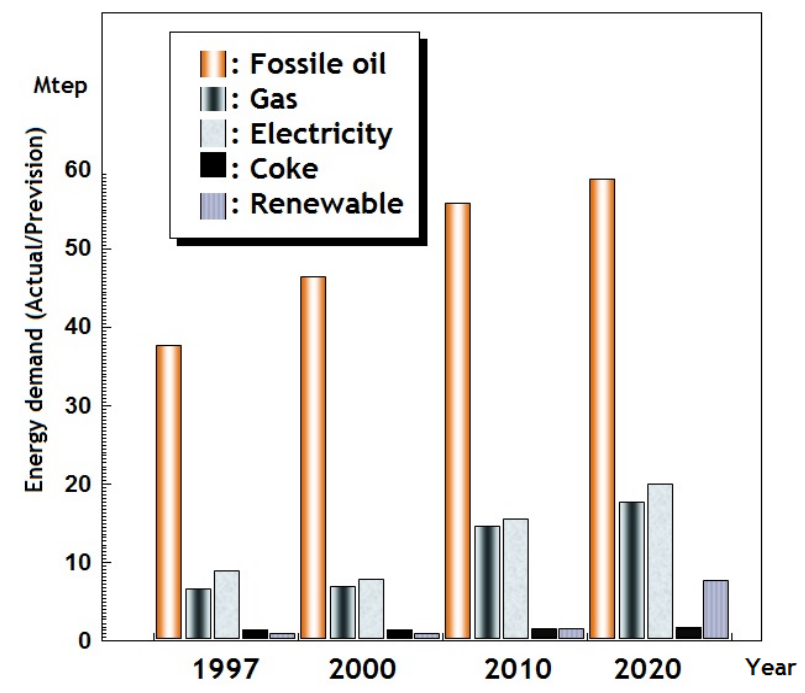

Fig. 4 Global demand of energy in the North Africa zone

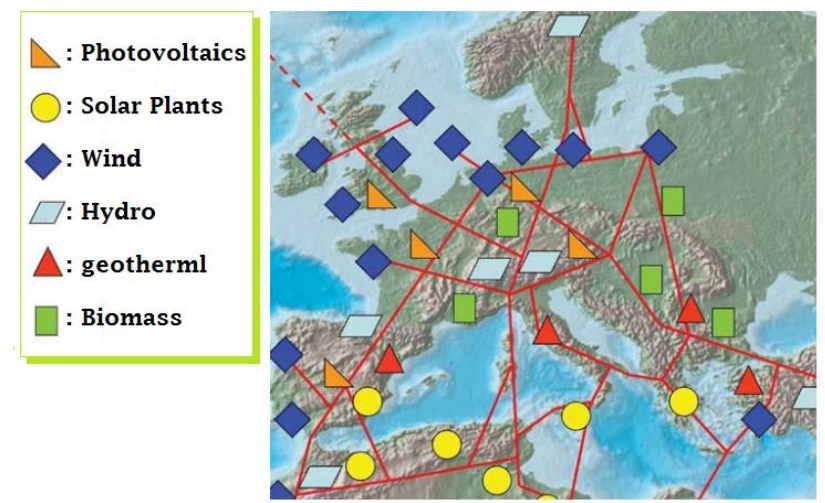

Fig. 5 Czisch European HVDC super grid synopsis

Establishment of the European HVDC super grid will lead to efficient and reliable renewable energy production.

Moreover, since that EU production alone would not provide reliable year round supply and would require expensive reserve generation and storage capacities, wind power as the best technology for large scale development presents a good solution. Associated to a common HVDC Supergrid, and integrated to relatively distant production centres like Tunisia and Morocco, Czisch plan (Czisch 2008; 2011), can provide clean power to all participating countries along with security against seasonal fluctuation.

\section{Results and discussion of the optimization scheme}

A fragment of Czisch European HVDC super grid is represented in Fig. 6. Impedance values as well as available power supply at each node are available at references (Czisch 2008; 2011). Under the hypothesis of a connection to the lower branch (ZX), the grid can be simplified to a 3-nodes circuit (Fig. 7).

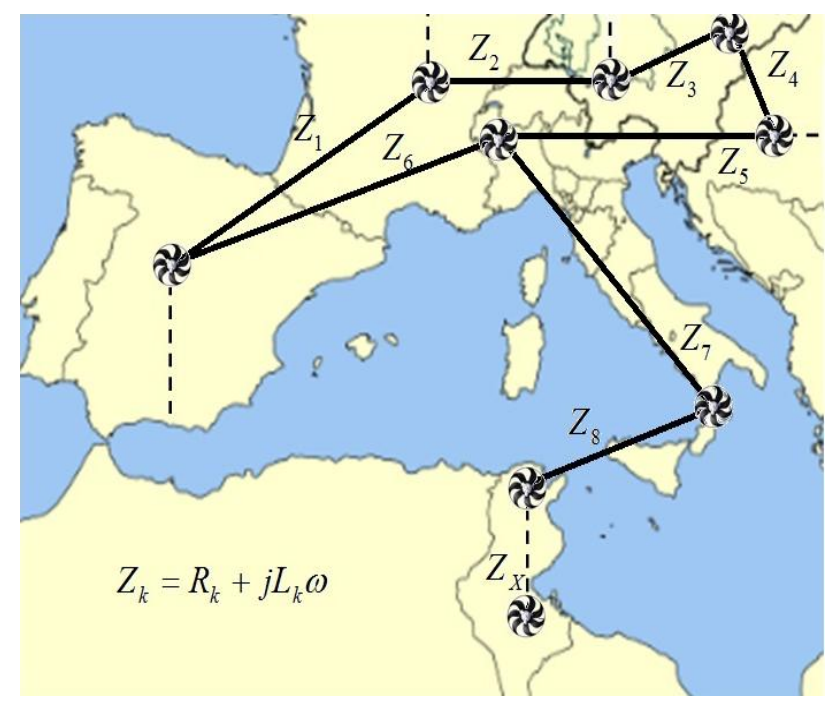

Fig. 6 A fragment of Czisch European HVDC super grid 


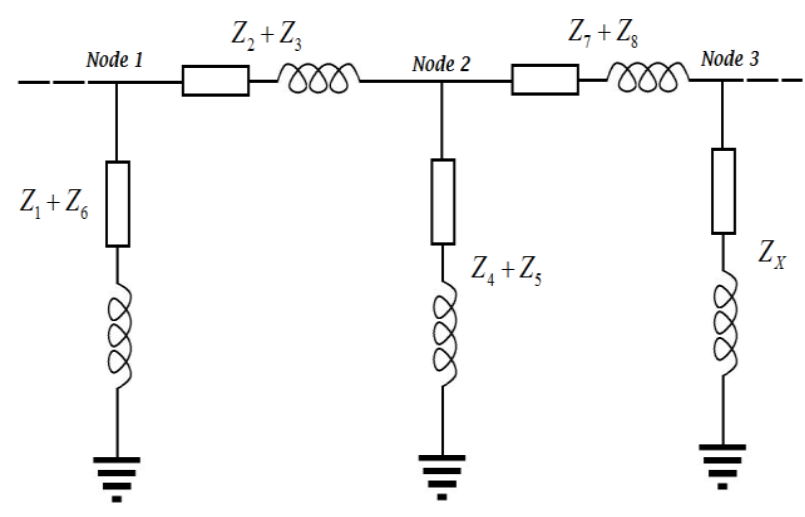

Fig. 7 HVDC super grid simplified equivalent electrical circuit

Based on circuit characteristics, along with the power available at each node, the approximated efficiency of the grid fragment could be plotted versus ZX modulus and the power presented at the level of the node 3 (additional branch in Fig. 6).

The first feature of the obtained plots of grid fragment efficiency versus ZX modulus and the power presented at the level of the node 3 (Fig. 8), is the obvious sensibility. In fact, efficiency fluctuation induced by the additional branch is about $17 \%$.

Contribution optimality can be recorded for the values of $650 \mathrm{MW}$ and $9 \Omega$ for the added power and ZX modulus, respectively. These values are in good agreement with the prediction of the Institut für Solare Energieversorgungstechnik (ISET) along with the proposed scenarios for a future electricity supply entirely with renewable energies (Czisch 2005). In fact, various concepts have been studied for providing renewable energies to Europe from neighbouring regions taking into account ECMWF data (ABB Power Transmission 2010; AWS Truewind 2004) as a source of information for the wind energy and photovoltaic potentials.

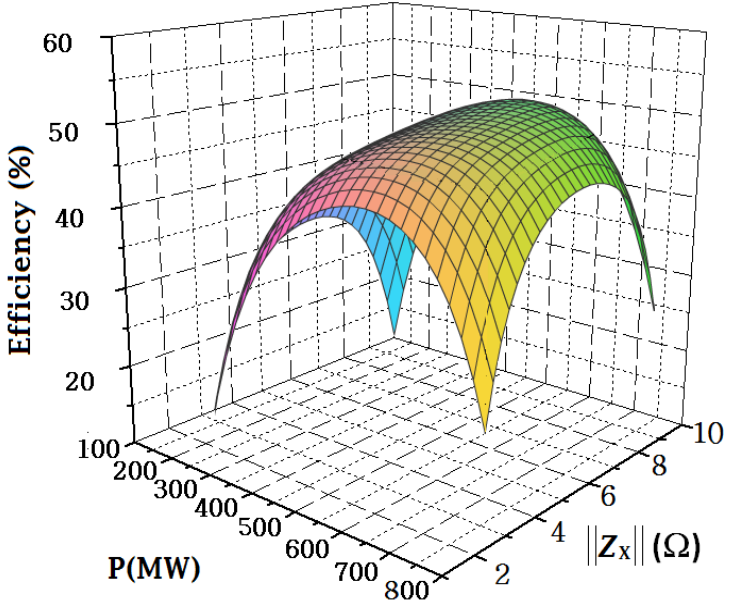

Fig. 8 Efficiency versus ZX modulus and the additional power
The performed optimisation process (AWS Truewind 2004) ensured that supply would meet demand at any time, including the dimensioning and operation of a HVDC grid that is superimposed on the current grid infrastructure. The criterion of optimisation, including the minimization of overall annual costs of electricity when fed into the regional high-voltage grids, yielded values of about 733 MW for energy supply from the targeted region, which is very close to the value proposed in the actual study.

\section{Conclusion}

In this work we have tried to discuss the actual situation in matter of wind energy in the upper region of North Africa. Energy potential and perspectives in the eastern North Africa region (Tunisia) have been investigated in terms of connectivity to the projected Czisch European HVDC super grid. A simplified extracted scheme of this grid has been used as a guide to optimize transportation efficiency through the whole net for 2025 horizons. An electrical simplified scheme analysis gave evidence to HVDC technology adequacy for economical power transmission over very long distances and connection between differently established grids.

A major issue of the presented analyses is about presumption on delays in energy polices. In fact, the EUCommission is going to prepare for a grid planning time of no more than 3 years. Planning and erection of wind parks does also not take longer. So it would be possible to go for relatively short planning horizons in line with the plans of the EU-Commission. Moreover, and ass local interests and national priorities do not seem to be in good agreements, the actual model, which supposed the existence of common energy policies $y$, is being revised in order to take into account this issue and evaluate separately, short-term and long-term features.

\section{References}

ABB Power Transmission (2010) HVDC Systems, ABB HVDC projects, Internet Publication http://www.abb.com/ (follow headword "HVDC Systems" and headword "ABB HVDC projects)".

AWS Truewind (2004) Wind Maps, Internet Publication , http://www.awstruewind.com/inner/windmaps/windmaps.htm.

Bahri, Y. (1991) Solar radiation intensity in Tunisia. Tunisian Energy Revue, 24, 37-42.

Ben Amar, F., Elamouri, M. \& Dhifaoui, R. (2006) Wind energetic potential in Tunisia. International congress on the engineering of renewable energies CERE' 2006, Hammamet, Tunisia.

Ben Jannet Allal, H. (2005) Energy and Eco-development in Tunisia. Report of Helio International, http://www.heliointernational.org/reports/pdfs/Tunisie-FR.pdf

Brand, B. \& Zingerle J. (2011) The renewable energy targets of the Maghreb Countries: impact on electricity supply and conventional power markets. Energy Policy, 39, 4411-4419.

Czisch G. (2008) Low Cost but Totally Renewable Electricity Supply for a Huge Supply Area, -a European/Trans-European Example, University of Kassel, Claverton Energy conference (Bath, UK: University of Kassel). Text at: http://www.iset.uni- 
kassel.de/abt/w3w/projekte/LowCostEuropElSup_revised_for_A KE_2006.pdf.

Czisch, G. (2005) Szenarien zur zukünftigen Stromversorgung Kostenoptimierte Variationen zur Versorgung Europas und seiner Nachbarn mit Strom aus erneuerbaren Energien, Dissertation, University of Kassel.

Czisch, G. (2011) Scenarios for a Future Electricity Supply: costoptimized variations on supplying Europe and its neighbours with electricity from renewable energies, translation of the German dissertation Szenarien zur zukünftigen Stromversorgung Kostenoptimierte Variationen zur Versorgung Europas und seiner Nachbarn mit Strom aus erneuerbaren Energien, The Institution of Engineering and Technology (IET) ISBN: 978-1-84919-156-2, $640 \mathrm{pp}$, London.

Elamouri, M., Ben Amar, F. \& Trabelsi, A. (2011) Vertical characterization of the wind mode and its effect on the wind farm profitability of Sidi Daoud-Tunisia. Energy Conversion and Management, 52, 1539-1549.

Hadj Sassi, B. and Gattoufi, B. (1988) Tunisian experience in the domain of wind energy éolienne. Tunisian Energy Revue, 14, 5359.

Kerkeni, C., BenJemaa, F., Kooli, S., Farhat, A. \& Maalej, M. (2002) Performance evaluation of a thermodynamic solar power plant: fifteen years of operation history. Renewable Energy, 25(3), 47387.

Khasri, M. (1986) L'energie eolienne en Tunisie. Meteorology National Institute (INM).
Khemiri, A. \& Hassairi, M. (2005) Development of energy efficiency improvement in the Tunisian hotel sector: a case study. Renewable Energy, 30(6), 903-911.

Mouldi B.M. (2003) Geothermal resource development in agriculture in Kebili region, Southern Tunisia. Geothermics, 32(4-6), 505-511.

Research Projects Federee (PRF) (2006) Wind Systems, Ministry of Superior Teaching and Technology, Tunisia, http://www.mrstdc.gov.tn/presentation/PRF/index.htm

Societe Tunisienne de l'Electricite et du Gaz (STEG) (2010) Large scale integration of solar and wind power in Mediterranean countries. MED 2010 Project, Contrat ENK5-CT-2000-00307, Direction of the Studies and Planning, Tunisia, http://www.steg.com.tn/fr/ institutionnel/electricite.html.

Trieb F. \& J. Nitsch (1998) Recommendations for the market introduction of solar thermal power stations, Renewable Energy, $14,17-22$.

Trieb F. \& Müller-Steinhagen H. (2008) Concentrating solar power for seawater desalination in the Middle East and North Africa, Desalination, 220, 165-183.

Trieb, F., Müller-Steinhagen, H. \& Kernb J. (2011) Financing concentrating solar power in the Middle East and North AfricaSubsidy or investment? Energy Policy, 39 (1), 307-317.

United Nations Environnement Programme (UNEP) (2004) Baseline for wind energy project in Tunisia. Workshop 18-20 March 2004, Tunisia-Hammamet. 